\title{
International Service Learning Program in Tourism Village Development Case Studies: Kampung Kabondok and Kampung Pasunga, Central Sumba, Indonesia
}

\author{
Christian Nindyaputra Octarino ", Reynaldo Yosua Wololi, and Arbiter Adi Wicaksono \\ Departement. of Architecture, Faculty of Architecture and Design, Duta Wacana Christian University, \\ Jl. Dr. Wahidin Sudirohusodo No. 5-25, Yogyakarta 55224, Indonesia
}

\begin{abstract}
Tourism is one of the leading sectors of Central Sumba District. In addition to natural environment, Central Sumba has rich of traditional culture that maintained in their social life. Kampung Pasunga, located in Anakalang village, is one of traditional village that have been designated as a Tourism Village by the local government. Kampung Kabondok, located in Makatakeri Village, not yet established as a tourist village but it has a great tourism potential because of their cultural traditions. This Service Learning Program focuses on mentoring and empowering the community in order to develop the tourism village. The participants for about $4 \mathrm{wk}$ stay with the local community to be able to understand the problems faced and then provide recommendations that need to be done. Infrastructure, quality of human resources, and tourism promotion are key problems in the development of a tourism village. Approach method and socializing with residents become a very important point, to ensure the proposed programs are the real need of the community. The final outcome are proposed programs or recommendations that divided into short, medium and long term, that will be presented to local community and stakeholders, as consideration for the local development plan.
\end{abstract}

Key words: Development plan, empowering community, service learning, tourism village

\section{Introduction}

\subsection{Sumba Island tourism}

As one of the areas in Eastern Indonesia, Sumba Island is a place that is rich in culture and natural beauty. Sumba Island tourism has been known by tourist around the world. Archaeologists dub Sumba as "the living megalithic Culture" because of their megalithic culture that still preserved more than $4500 \mathrm{yr}$ old. This megalithic cultural relics such as

* Corresponding author: christian.octarino@staff.ukdw.ac.id 
tombs stones that can be easily found either in the home yard in each township residents and each Kampung Adat. Sumba Island consists of four districts that are West Sumba, Southwest Sumba, Central Sumba, and East Sumba. The potential of tourism and culture on Sumba Island spread evenly in each of these districts.

Central Sumba is a new district from the expansion of West Sumba in 2007. The tourism sector is also a potential in Central Sumba Regency, with major attractions such as Kampung Adat and nautical tourism. Kampung Adat in Central Sumba is believed to be one of the oldest Kampung adat in Sumba Island, which is home to the ancestors of the Sumbanese people. Therefore, it is not surprising that the cultural tradition in Central Sumba is still very strong. Various kinds of traditional ceremonies can be easily found in every village, such as weddings and grief. The ceremonies always involve the community and the animals in large numbers, so it is a great cultural treasure to be a tourist attraction for tourists that came to Central Sumba.

\subsection{Tourism village development}

Tourism village development is one of the important programs to be realized in Central Sumba, in terms of the high potential of culture that already exist. Kampung Adat in Central Sumba has a rich culture that looks tangible and intangible. Traditional houses and stone graves are a form of physical/tangible cultural wealth while traditional ceremonies become intangible cultural traditions that can be the main attractions of Kampung Adat in Central Sumba. Tourism village is an area in the form of a rural environment that has a tourist attraction based on local wisdom such as manners, culture, and natural resources that has a uniqueness and authenticity in the form of a characteristic rural atmosphere [1]. Currently the attractions owned by Kampung Adat in Central Sumba have not been able to run optimally because it has not been supported by accommodation and good support facilities. This is a major concern for the local government for the tourism sector of Central Sumba can be increased.

Kampung Kabondok and Pasunga are two Kampung Adat located in Central Sumba Regency, which has huge potential as a tourist village. Kampung Pasunga has even been established by the government as a tourist village. In this village there is a large stone grave, located in the middle and front yard of the village. Stone grave became the main attraction of Kampung Pasunga, apart from existing traditional house. While Kampung Kabondok, although not yet established as a tourist village, but has great tourism potential due to a very strong cultural tradition. This is seen with the existence of a large grave which is the tomb of King Anakalang. Besides its location is also within walking distance of the village of Lai Tarung, traditional village which became the venue for the traditional ritual "Purung Takadonga Ratu". Both the traditional village have a great potential, if supported by appropriate programs will be able to support tourism in Central Sumba Regency.

\subsection{International field school thematic service-learning}

International Field School Thematic Service-Learning (IFSTS-L) is a collaborative program between the Duta Wacana Christian University Yogyakarta, Indonesia and Australia National University, Australia that has been running since 2009. This program is held annually with different locations. In 2016, with the MoU between the UKDW and the local government of Central Sumba Regency, the IFSTS-L 2016 program takes place in Central Sumba Regency.

Service learning is regarded as innovative pedagogy that enriches classroom practice, as well as an avenue to civic engagement [2]. This program focused on the learning process from the local community along with the conditions in which they live. Service learning is 
not a prepared project, but a result of an approach to the local community, finding out what the problems and potentials of the community are. Service learning also combines both academic topics and community service that is mutually beneficial for the participant and community involved [3].

Communicating skill is something that is very important because with good communication information will be obtained completely and precisely. Good communication is not only made to the local community, but also among the participants. The results of the approach to the local community will be formulated into regional development programs and also for the community empowerment program as the solution of existing problems.

The theme of IFSTS-L 2016 in Central Sumba Regency is "Developing Local Potentials for Sustainable Tourism Village". Based on the theme, IFSTS-L programs will be directed to developing kampung wisata/tourism village by developing the communities in Central Sumba District to be totally participatory in order to improve the welfare of the local community.

\section{Methodology}

\subsection{IFSTS-L program}

IFSTS-L 2016 was attended by 56 participants, consisting of 32 students from UKDW and 24 students from ANU. The participants were divided into 10 groups, each consisting of five members to six members from UKDW and ANU. For 4 wk the participants settled and lived in 10 different villages, two of which were Kampung Pasunga and Kampung Kabondok.

As seen in Figure 1, the implementation of IFSTS-L activities is divided into several steps. Especially for participants from UKDW, they have been provided about the portrait of Central Sumba area in general and some courses and workshops that support the Service Learning process. Then for four wk in the location the participants had several phases of activity. The first week is the phase of data collection, each group in each hamlet focus to observe and explore information about the potential of the area and the problems that exist in the community. Then for $2 \mathrm{wk}$ participants are expected to formulate and implement the program in accordance with what is obtained. The final phase is writing the report and then presenting the results in front of Central Sumba Regent regional leaders and staffs.

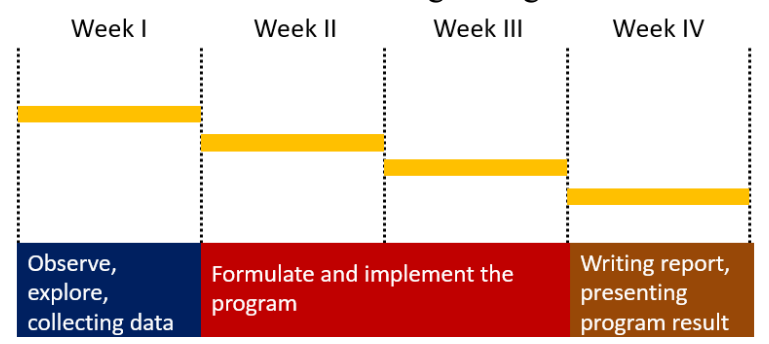

Fig. 1. Time line of IFSTSL program.

\subsection{Community based development}

The IFSTS-L program is based on the local community. This program uses community based development method, so that the entire proposed program comes from the community and supported by local resources. Community based development is considered 
as one of the fastest growing planning mechanisms for delivering idea and assistance [4]. The perception of local people is important to know in order to understand the significance and value of local participation that has been running. The main program in Kampung Kabondok and Pasunga is the development of a tourism village based on community empowerment. Community-based tourism is a tourism development approach that emphasizes the local community either directly or indirectly involved in the tourism industry. This community-based approach method is expected to be able to maintain the sustainability of the tourism development program in both villages. The community is invited to participate because they are understood to fully understand their needs, understand the social and economic conditions of the local community, and be able to utilize the available resources [5]. The concept of community based tourism is the basis of sustainable tourism development, which asserts that community is no longer the object of development but as a determinant of development itself [6]. In addition, coordination with the government is also important to encourage the improvement of regional infrastructure that supports tourism activities. Many community based tourism (CBT) programs have failed due to lack of financial feasibility, and poor governance [7]. The level of community participation in local government structures will determine the success of CBT itself. When CBT works effectively, it will get the following benefits [8]:

i) supports local economic development through diversification of employment

ii) financially viable

iii) respects and encourages equitable participation of local community

iv) ecologically sustainable and minimizes impact on the environment

v) conserves and promotes living cultural heritage and welfare

vi) educates visitors about culture and nature

vii) demonstrates good management practices

viii) Ensures a quality and safe experience for all of individuals involved.

Communication with local communities is key to the success of this program. The participants have been equipped with several methods about how to interact with the community. Open-ended, flexible, or non-structured interviews usually it will be more effective to get more information. The keynote is active listening, allowing the respondent to talk freely and ascribe meanings, while keeping in mind the broader aim of the research. The participants must be able to explore the problem deeply to avoid any initial hypotheses that are not in accordance with the actual conditions. Proper speculation will ease the process of developing grounded theory for qualitative analysis [9]. In some circumstances, also require focused discussion among participants and community, called focus group discussion. The advantage with focus groups is the actual interaction between the groups participants since they can build their thoughts upon the contributions made by others, as if they were brainstorming about a topic together. This way they might inspire one another and create new and more elaborated ideas through an active discussion [10].

\section{Workshop and discussion}

\subsection{Kampung Kabondok}

Kabondok is a significant hamlet located in Makata Keri, Sumba Tengah that lays claim to being the main Kampung of the Kingdom of Anakalang. The kampung is made up of 15 mainly semi-traditionally built homes and is located within walking distance of the town center of Waibakul (Figure 2). Residents of Kabondok are made up of farmers, teachers, retirees, government employees, school aged children and infants. Each household often holds three generations of the one family and the number of people in each property 
fluctuates with extended family often visiting. It is also usual for family members to be studying or living on other islands that are more developed, and where education and job prospects outside of agriculture are better.
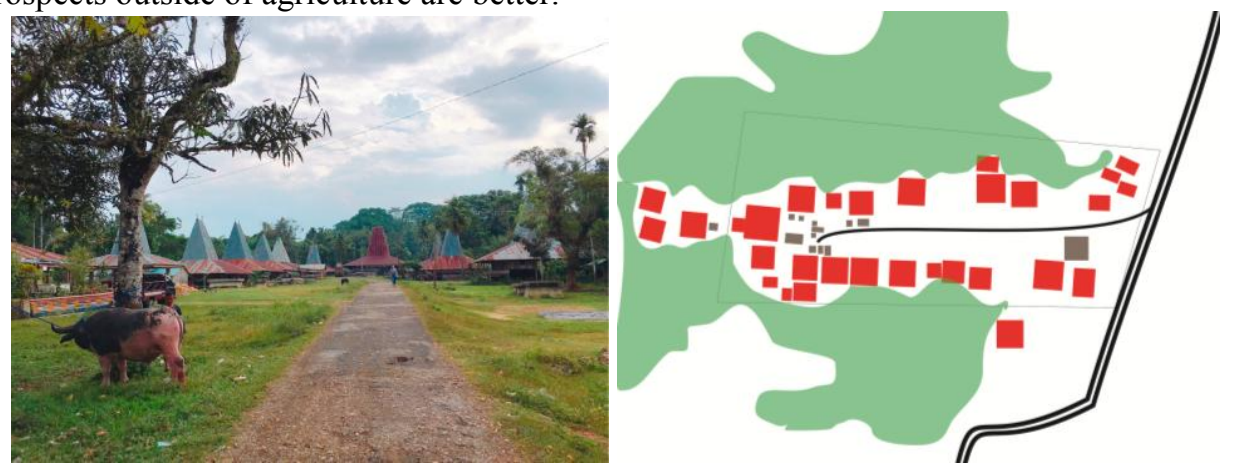

Fig. 2. Mapping of Kampung Kabondok.

\subsubsection{Problem and opportunities}

Kampung Kabondok has a great potential to be developed as a tourism village, with a rich culture and tradition. The main attraction owned by Kampung Kabondok is their traditional houses and stone graves. Kabondok is home to two graves that are important tourist sites. The most outstanding grave is Watu Raihi Moni, the grave of the Anakalang King. It is most notable because of the large and intricate tombstone that stands in front of it, and is associated with multiple myths. This village also has a close distance to Kampung Adat Lai Tarung, one of indigenous kampung that is still considered sacred by local residents. Another potential is a walking trail connecting Kampung Kabondok, Lai Tarung, and Anakalang. The track provides spectacular views across rice fields and a nice walk through jungle areas.

Although it has lot of attraction, but in fact the number of tourists who come to Kabondok can be said to be minimal. It is become a major problem in effort to develop Kabondok as a tourism village. According to data from visitor books stored by one of the residents, the number of visitors has increased each year, but it is still relatively small (Figure 3).
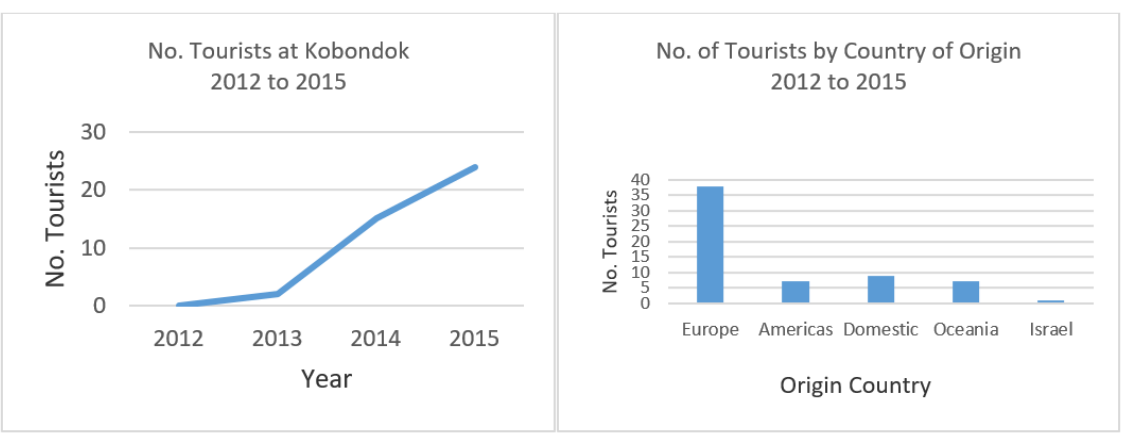

Fig. 3. Number of Tourist in Kampung Kabondok (left), Number of tourist by origin country (right).

A meeting arranged with Sumba Tengah's Tourism department described the following issues as correlating with Kabondok's low guest numbers, in comparison to other more developed tourist locations in Sumba. 
i) Tourism funding depends on local revenue which is currently very low, and as such there are very limited funds available to the Tourism Department for the further development and promotion of Kabondok and Lai Tarung.

ii) Resources are limited and are stretched across a small number of locations throughout Sumba Tengah, including Pasunga as the region's designated tourist village.

iii) Indonesia's current national focus is on education, infrastructure and health, meaning that tourism is not an immediate priority within Indonesia.

iv) Limited human resources and capacity, with only one appropriately qualified employee currently working at the Tourism Department.

After further discussions with residents were held, there seemed to be little interest in promoting the kampung as its own tourist attraction. Many consider that Kabondok is one part of a larger tourism network along with Kampung Lai Tarung, but this promotion is still very less. Discussions had with one village resident - an employed guide and the keeper of Lai Tarung - Umbu Dongu, has expressed a lack of motivation from residents in regards to tourism potential within the hamlet. He also stated that the arrival of tourists did not seem to bring significant economic changes.

Based on the results of the discussion it can be concluded that the main problems that hinder the development of Kampung Kabondok tourist village are the limited allocation of government funds, lack of promotion, and limited human resources.

\subsubsection{Problem and opportunities}

Judging from the level of the existing problems, it is not possible for the participants to solve everything during their stay. Each issue requires coordination between many parts of communities and will take quite a long time. Therefore, the program will be divided into short and long term programs.

Short-term program is a program that can be done on the spot during their stay and does not require too much preparation. Short-term programs as well as community empowerment so that the community can continue what has been started by the participants and the program can be sustainable. The short-term programs held in Kampung Kabondok include:

i) Initiate a meeting between village representatives and the government (Tourism department). Meetings between the community and the government need to be done regularly to be able to coordinate in planning the development of traditional kampung.

ii) English lessons for local children and teenagers. One of the problems of tourism village development is human resources. Most tourists who come are foreign tourists, and people find it difficult to provide information with foreign language. This program is expected to improve the community's ability to speak in English so that they ready to interact directly with foreign tourists.

While the long-term program is a recommendation program that is given both to the community and also to the local government. Recommendations provide include:

i) Continued funding and government support for Purung Ta Kadonga Ratu and better dissemination of event advertising to attract more domestic and international tourists. For example, flyers to be provided to hotels in Sumba and other neighboring islands, and the government website to be regularly updated and maintained.

ii) Conduct more intense promotion, both regional and international levels

iii) Work on building a stronger relationship between Kabondok, Anakalang and Lai Tarung, with the aim of better promoting the walking track that connects all three 
hamlets. Additionally, working with Pasunga as a possible recruitment and starting point for tourists interested in exploring further than Pasunga itself.

\subsection{Kampung Kabondok}

Pasunga is an official tourism village 'kampung adat' located on the main street of Waibakul. It was rebuilt in this location as a centre of attraction to promote traditional culture in Central Sumba. As seen in Figure 4, Pasunga has a linear housing layout and consist of nearly 200 residents. Pasunga has close access to transport, health and education facilities. The village has access to electricity, local shops and markets.
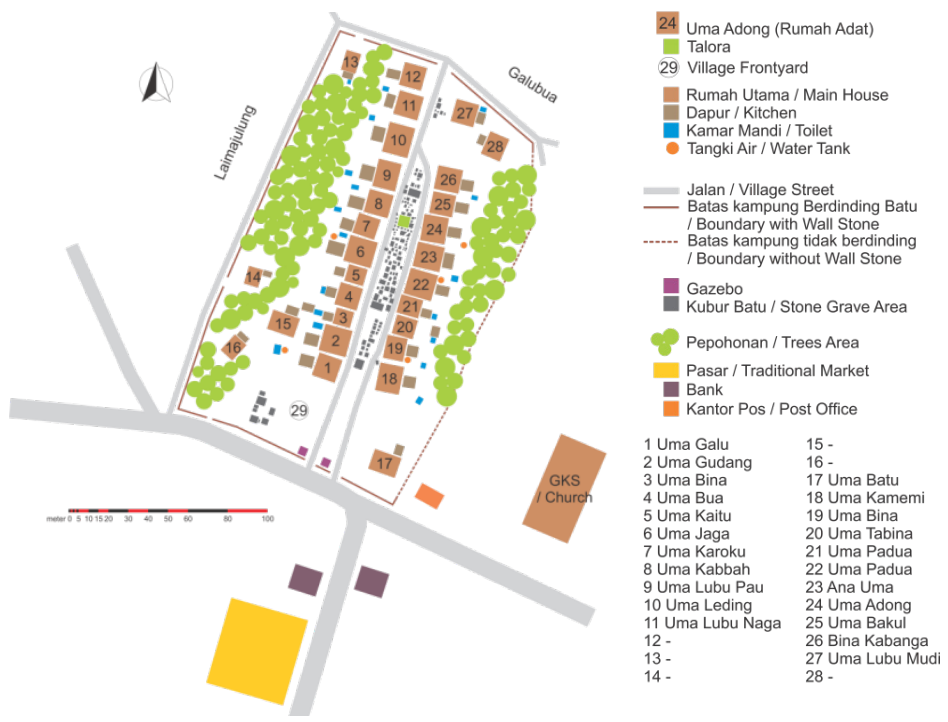

Fig. 4. Mapping of Kampung Pasunga.

\subsubsection{Problem and opportunities}

Based on the results of discussions with local residents both formally and non-formally obtained various information about the condition of Kampung Pasunga in the development effort as Tourism Village. Some of the main potentials that become the excellence of Kampung Pasunga include:

i) Wealth of tradition and culture in the form of traditional house and also megalithic tomb. Kampung Pasunga is one of the villages with the largest number of stone graves, with various sizes and reliefs.

ii) Kampung Pasunga is located directly on Waibakul main road, so it has very easy access. This is very beneficial because this village will be seen clearly by tourists passing by on the main road

iii) The official "Tourism Village" status given by the government to be an advantage, Kampung Pasunga will be a priority in the allocation of funding related to tourism development

Apart from its potential, Kampung Pasunga also still has some problems in the development of Tourism Village. These problems include:

i) Infrastructure issue

The main problem lies in the limited availability of water. Unlike other villages, Pasunga does not have a well or a good water flow. The existing water network 
was damaged and there has been no improvement by the local government. Residents must purchase clean water which is quite costly, or take water in the water source which is takes time (Figure 5). The next problem is related to electricity. Not all homes are connected to the grid, and there are regular blackouts every $3 \mathrm{~d}$.

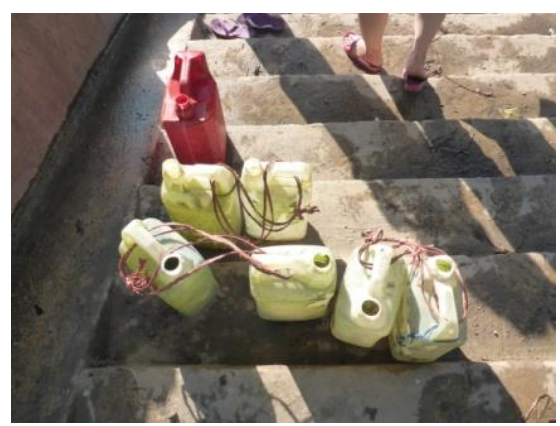

Fig. 5. Small water containers to contain water from water spring.

ii) Tourism development issue

The number of tourists who come to Kampung Pasunga is relatively small. This is judged as a result of the lack of promotion and information related to the potential of Kampung which can be the main attraction for tourists. Most tourists know the existence of Kampung only through information from local residents. Some tourist even drew their own map to got clearly information (Figure 6). In addition, the lack of accommodation facilities is also the cause of the tourists prefer to live in other areas such as Waikabubak or Tambolaka. All tourists suggested making more information available online so that locations and sites can be found easily.

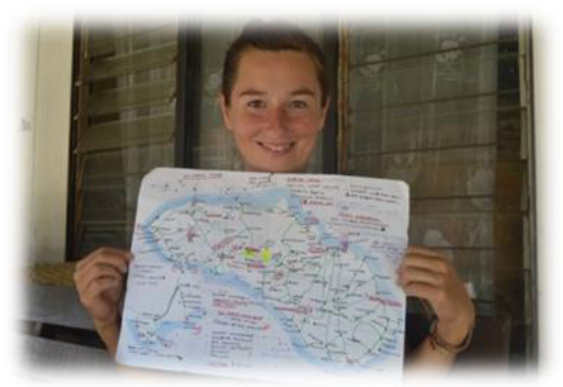

Fig. 6. Tourist drew a map herself because of the lack of information.

\subsubsection{Program and solution}

Developing village tourism will take a long time to complete. But there are some things that can be done in the short term, including:

i) Increased promotion through websites and social media

This program includes mentoring and training to create a website for promotion. (The website interface can be seen in Figure 7). Also provided training for website maintenance so that in the future the local community can manage their own.

ii) Making information facilities related to Kampung Pasunga

Information facilities include tourism calendar, regional tourism map, and map of Pasunga.

iii) English lessons for children and teenagers 
The program is carried out to prepare the local community to interact with foreign tourists, so that information can be conveyed more optimal.

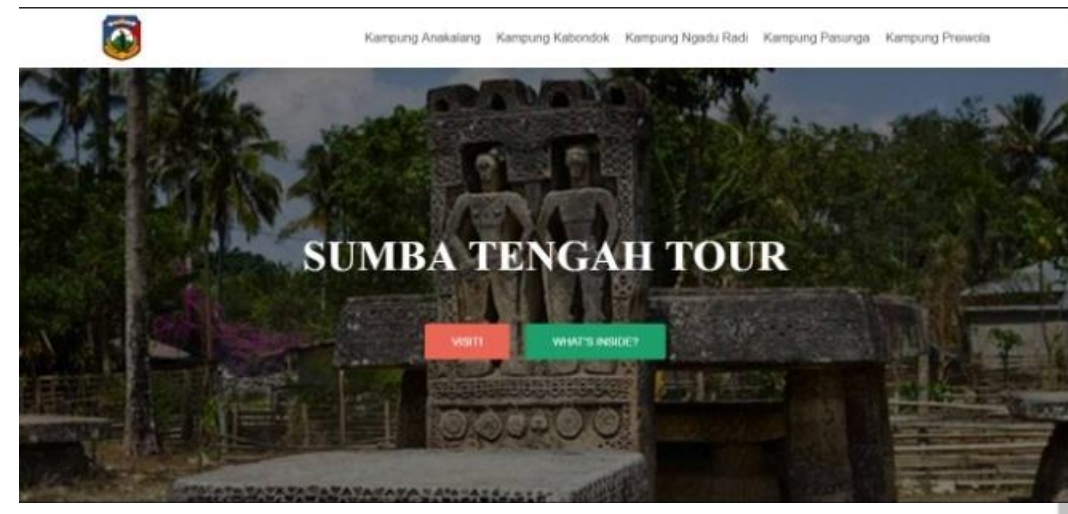

DESA ANAKALANG \& MAKATAKERI
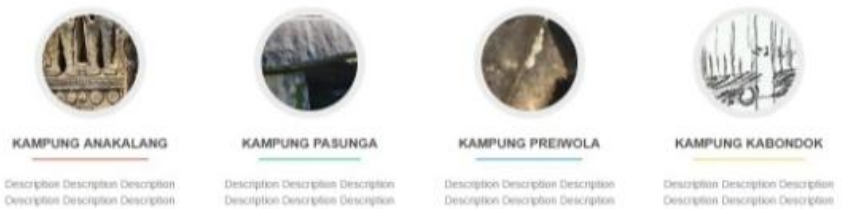

Fig. 7. Tourism website prototype.

For long-term programs, recommendations are provided to local communities and governments. Recommendations include:

i) Increased infrastructure and accommodation facilities in Kampung Pasunga. As a tourism village that has been inaugurated by the government, it is expected that the allocation of funding to build infrastructure (especially on water and electricity networks) can be prioritized, so that other planning can be more easily done. In addition, it is necessary to improve the accommodation facilities to accommodate tourists who want to stay for a long time.

ii) Increase promotion through various media. Then improve the quality of human resources through both language training and skills in the use of technology

\section{Conclusion}

In effort to develop a tourism village in the Kampung Kabondok and Pasunga, there are still some problems encountered. The main problems encountered are related to Infrastructure, promotion, and human resources. Several programs have been planned and implemented by IFSTS-L participants to support the development of a tourism village. Short-term program is intended as a solution to the problem with a relatively narrow scope, and also as a stimulant for the community to be able to develop independently. Which are classified as short-term programs such as language training, making of regional map, website training, etc. While the long-term program aimed to resolve problems in a larger scope, which cannot be solved in a short time. This program is usually a recommendation for the village community and also to the local government. All programs emphasize community empowerment so that they can develop and manage independently. It aims to create tourism in Kampung Kabondok and Pasunga into a sustainable community based tourism. 


\subsection{Lessons learned by the participants}

Through this Service Learning program many kind of experiences gained by participants, not only hard skill but also soft skill. In running the program the participants will be able to increase the hard skill according to their related fields. For example, architecture students help in making regional mapping and tourism master plan, IT students help in the training of creating websites, etc. In soft skill, a lot of experience is gained by the participants. With the feeling of living together, participants learn how to interact with local communities that have a much different culture, and learn how to appreciate the local culture. In addition, participants learn to explore local potentials, collaborate with local communities, and empower communities, not just to give. It is expected that the experience gained through this Service Learning program can benefit the future of the participants, both in the academic and professional world.

\section{References}

1. H. Hermawan. Jurnal Pariwisata, 3, 2:105-117 (2016). [in Bahasa Indonesia] http://ejournal.bsi.ac.id/ejurnal/index.php/jp/article/view/1383

2. G.A. Bowen, P.M. Kiser. Journal of Higher Education Outreach and Engagement, 13, 1:27-43(2009). http://files.eric.ed.gov/fulltext/EJ905391.pdf

3. W.K. Lee, C.C.D. Harris, K.A. Mortensen, L.M. Long, J. Sugimoto-Matsuda. BMC Med Educ, 16:137(2016). https://doi.org/10.1186/s12909-016-0664-7

4. G. Mansuri, R. Vijayendra. The World Bank Research Observer, 19, 1:1-39 (2004). https://openknowledge.worldbank.org/bitstream/handle/10986/14310/wps3209commu nity.pdf?sequence $=1$

5. L. Widaningsih, B. Tjahyani, E. Krisnanto. TERAS, VIII, 1:73-83(2008). [In Bahasa Indonesia]. http://garuda.ristekdikti.go.id/journal/article/448355

6. I W. Ardika. Pariwisata Bali: membangun pariwisata-budaya dan mengendalikan budaya pariwisata. [Bali tourism: developing and controlling tourism-culture]. In: Bali menuju Jagaditha: aneka perspektif [Bali into Jagaditha: various perspective].

A.A.G.N.A. Dwipayana, I.N.D. Putra (Eds). Denpasar: Pustaka Bali Post (2004). pp. 20-33. [in Bahasa Indonesia].

https://books.google.co.id/books/about/Bali_menuju jagaditha.html?id=8ZxxAAAAM AAJ\&redir_esc $=$ y

7. J. Mitchell, P. Muckosy. Opinion 102 A misguided quest: community-based tourism in Latin America. [Online] from

https://assets.publishing.service.gov.uk/media/57a08bd2e5274a27b2000d9d/tourismOpPaper.pdf. (2008). [Accessed on 28 October 2017]

8. S. Asker, L. Boronyak, N. Carrard, M. Paddon. Effective community based tourism: a best practice manual. sustainable tourism cooperative research centre [Online] from www.aknl.net/APEC\%20Effective \%20Community\%20Based\%20Tourism\%20WEB.p df (2010). [Accessed on 28 October 2017]

9. D. Silverman. Interpreting qualitative data: A guide to principles of qualitative research. 4th ed. London: Sage Publications Ltd. pp. 60-61 (2011). https://books.google.co.id/books/about/Interpreting_Qualitative_Data.html?id=gRKCIf yEsdEC\&redir_esc $=y$

10. D.R. Cooper, P.S. Schindler. Business Research Methods. 12th ed. London: McGraw Hill. pp. 160-162 (2014): https://www.amazon.com/Business-Research-MethodsDonald-Cooper/dp/0073521507 